\title{
The sigma ligand, igmesine, inhibits cholera toxin and Escherichia coli enterotoxin induced jejunal secretion in the rat
}

\author{
J L Turvill, P Kasapidis, M J G Farthing
}

\begin{abstract}
Background-Cholera toxin, and Escherichia coli heat labile (LT) and heat stable (STa) enterotoxins induce small intestinal secretion in part by activating enteric nerves. Igmesine is a novel sigma receptor ligand that inhibits neurally mediated secretion.

Aims-To assess the antisecretory potential of igmesine in cholera toxin, LT, and STa induced water and electrolyte secretion using an in vivo rat model of jejunal perfusion.
\end{abstract}

Methods-After pretreatment with igmesine, 0.03-10 mg/kg intravenously, jejunal segments of anaesthetised, adult male Wistar rats were incubated with cholera toxin $(25 \mu \mathrm{g})$, LT $(25 \mu \mathrm{g})$, or saline. Jejunal perfusion with a plasma electrolyte solution containing a non-absorbable marker was undertaken. In some cases $200 \mu \mathrm{g} / 1$ STa was added to the perfusate. After equilibration, net water and electrolyte movement was determined. In additional experiments rats received igmesine, intravenously or intrajejunally, after exposure to cholera toxin.

Results-Cholera toxin induced net water secretion was inhibited by $1 \mathrm{mg} / \mathrm{kg}$ igmesine (median -120 versus $-31 \mu 1 / \mathrm{min} / \mathrm{g}$, p<0.001). LT and STa induced secretion were also inhibited by $1 \mathrm{mg} / \mathrm{kg}$ igmesine ( -90 versus $-56, p<0.03$; and -76 versus $-29, p<0.01$, respectively). Igmesine reduced established cholera toxin induced secretion.

Conclusion-The sigma ligand, igmesine, inhibits neurally mediated enterotoxigenic secretion. Its ability to inhibit established secretion makes it an agent with therapeutic potential.

(Gut 1999;45:564-569)

Digestive Diseases Research Centre, St Bartholomew's and The Royal London School of Medicine and Dentistry, Turner Street, London E1 2AD, UK

J L Turvill

$P$ Kasapidis

M J G Farthing

Correspondence to: Dr Turvill.

Accepted for publication 14 April 1999
Keywords: igmesine; cholera toxin; Escherichia coli enterotoxin; jejunal secretion

The diarrhoeal diseases caused by infection with Vibrio cholerae and enterotoxigenic Escherichia coli are characterised by the production of highly potent enterotoxins. ${ }^{1}$ Binding of these enterotoxins to the small intestinal epithelium results in the activation of cyclic nucleotide second messenger systems which initiate metabolic cascades characterised by the opening of apical chloride channels and the onset of small intestinal secretion. Cholera toxin and $E$ coli heat labile enterotoxin (LT) stimulate the intracellular synthesis of cyclic $\mathrm{AMP}$, while $E$ coli heat stable enterotoxin (STa) increases cyclic GMP. ${ }^{2-4}$ All three enterotoxins additionally promote secretion through activation of the enteric nervous system. ${ }^{5}$

Oral rehydration solutions have become the mainstay of therapy for such diseases, which continue to be major causes of morbidity and mortality worldwide. Although antibiotics such as tetracycline and the fluoroquinolones can reduce the duration and severity of these illnesses, there is not yet widely available a truly antisecretory agent that can pharmacologically inhibit enterotoxin induced secretion and so ameliorate the severity of the diarrhoeal illness. $^{6-8}$

In 1976, Martin et al attributed one of the three major profiles of opioid associated effects in the dog (canine delirium) to a putative fourth opiate receptor designated sigma. ${ }^{9}$ Later, because of its insensitivity to blockade by naloxone and its enantioselectivity, it became clear that the sigma receptor was not a type of opiate receptor. It was declassified and is now considered as a separate receptor class. Sigma receptors are found throughout the central nervous system, but their function remains unclear. It has been proposed that they attenuate the ability of acetylcholine to activate the phosphoinositide second messenger system, possibly by inducing the internalisation of cholinergic receptors. ${ }^{10}$ In 1988, Roman et al presented evidence for the existence of sigma sites in guinea pig myenteric plexus. ${ }^{11}$ Further autoradiographic studies have revealed the existence of a dense distribution of sigma binding sites in the mucosa and submucosa of guinea pig intestine. ${ }^{12}$ Then, in 1989 a functional role for these receptors in modulating intestinal motility was suggested. Campbell et al showed that longitudinal muscle contraction induced by electrical stimulation of myenteric plexus was blocked by the prototypical sigma ligand, (+)-SKF 10,047. ${ }^{13}$ This was accompanied by the inhibition of acetylcholine release. Since this initial observation, Pascaud et al and others have also proposed that sigma ligands influence intestinal water and electrolyte transport. ${ }^{14-16}$

Recently the highly selective sigma ligand, igmesine (JO 1784, (+)-cinnamyl-1-phenyl$1-N$-methyl- $N$-cyclo-propylene) has been

Abbreviations used in this paper: $\mathrm{CT}$, cholera toxin; 5-HT, 5-hydroxytryptamine; LT, Escherichia coli heat labile enterotoxin; NPY, neuropeptide Y; PEG, polyethylene glycol 4000; PES, plasma electrolyte solution; STa, Escherichia coli heat stable enterotoxin; VIP, vasoactive intestinal polypeptide. 
described. ${ }^{17}$ It is capable of displacing tritiated (+)-SKF 10,047 from brain sites in mice and is effective when administered parenterally or orally. Furthermore, it seems to have antisecretory properties. Igmesine reverses vasoactive intestinal polypeptide (VIP) induced increases in short circuit current in stripped ileal sheets mounted in Ussing chambers, and in vivo studies in mouse and man have showed that igmesine inhibits prostaglandin induced diarrhoea. ${ }^{18} 19$

As both VIP and prostaglandins have been implicated as secretagogues in the pathophysiology of enterotoxigenic small intestinal water and electrolyte secretion, we determined whether igmesine would inhibit cholera toxin, LT, or STa induced secretion. ${ }^{2021}$ An established in vivo rat model of small intestinal perfusion was used. ${ }^{22}$

\section{Methods}

BASIC EXPERIMENTAL DESIGN

Adult male Wistar rats (180-220 g body weight), fasted for 18 hours with free access to water, were anaesthetised with intraperitoneal sodium pentobarbitone $(60 \mathrm{mg} / \mathrm{kg})$ and maintained by interval injections $(15-30 \mathrm{mg} /$ $\mathrm{kg}$ ) as necessary throughout the experiment. Body temperature was maintained at $37^{\circ} \mathrm{C}$ using a heat pad. The abdomen was opened through a midline incision and a $20 \mathrm{~cm}$ jejunal segment was created by the insertion of a proximal cannula into the small intestine $5 \mathrm{~cm}$ beyond the duodenojejunal flexure and a second cannula $20 \mathrm{~cm}$ more distally. Both cannulae were ligated as previously described. ${ }^{22}$ The isolated segment was gently flushed with isotonic saline $\left(37^{\circ} \mathrm{C}\right)$ and air to clear it of residual contents, the intestine was returned to the abdominal cavity, and the abdomen closed.

The jejunal segment was then perfused at a rate of $0.5 \mathrm{ml} / \mathrm{min}$ with plasma electrolyte solution (PES) containing Na $140 \mathrm{mmol} / \mathrm{l}, \mathrm{K} 4$ $\mathrm{mmol} / \mathrm{l}, \mathrm{Cl} 104 \mathrm{mmol} / \mathrm{l}$, and $\mathrm{HCO}_{3} 40 \mathrm{mmol} / 1$ to which $5 \mathrm{~g} / 1$ polyethylene glycol 4000 (PEG) and $4 \mu \mathrm{Ci} / 1$ of ${ }^{14} \mathrm{C}$-PEG had been added. Thirty minutes were allowed to elapse to ensure establishment of a steady state after which three consecutive 10 minute collections of the effluent were obtained from the distal cannula. The samples were stored at $-50^{\circ} \mathrm{C}$ for up to 48 hours prior to analysis of ${ }^{14} \mathrm{C}-\mathrm{PEG}$ and electrolyte concentration. At the end of the experiment rats were killed by an overdose of pentobarbitone; the perfused segment was removed, rinsed, blotted, and desiccated in an oven at $100^{\circ} \mathrm{C}$ for 18 hours to obtain the dry weight.

\section{BASAL STATE EXPERIMENTS}

Fifteen minutes before jejunal perfusion was undertaken, rats were intravenously pretreated with $10 \mathrm{mg} / \mathrm{kg}$ igmesine, dissolved in $0.25 \mathrm{ml}$ saline, or saline alone.

CHOLERA TOXIN EXPERIMENTS

Three groups of experiments were carried out:

Intravenous administration of igmesine before cholera toxin exposure - Rats were intravenously pretreated with $0.03,0.1,0.3,1,3$ or $10 \mathrm{mg} / \mathrm{kg}$ igmesine or saline alone. Fifteen minutes later
$25 \mu \mathrm{g}$ cholera toxin in $2 \mathrm{ml}$ isotonic saline was instilled into the isolated segment and both cannulae were clamped. After two hours incubation, the clamps were removed and the jejunal perfusion commenced as described above.

Intravenous administration of igmesine after cholera toxin exposure-Rats were incubated with $25 \mu \mathrm{g}$ cholera toxin as described above. After an initial 30 minute period of perfusion to confirm the onset of secretion, rats intravenously received 0.3 or $1 \mathrm{mg} / \mathrm{kg}$ igmesine in 0.25 $\mathrm{ml}$ saline or saline alone. The perfusion was then extended for a further 30 minutes.

Luminal administration of igmesine after cholera toxin exposure-Rats were incubated with $25 \mu \mathrm{g}$ cholera toxin as described above. Igmesine 40 $\mu \mathrm{g} / \mathrm{ml}$ was added to the plasma electrolyte perfusion fluid and was present throughout the experiment.

\section{LT EXPERIMENTS}

Isolated jejunal segments, prepared as described above, were intravenously pretreated with $1 \mathrm{mg} / \mathrm{kg}$ igmesine or saline alone $15 \mathrm{~min}$ utes prior to incubation with $25 \mu \mathrm{g}$ LT in $2 \mathrm{ml}$ saline. After two hours in situ jejunal perfusion was undertaken to determine net water and electrolyte movement.

\section{STa EXPERIMENTS}

Isolated jejunal segments were prepared as described above. Rats were intravenously pretreated with $1 \mathrm{mg} / \mathrm{kg}$ igmesine or saline. Fifteen minutes later in situ small intestinal perfusion was undertaken using PES into which $200 \mu \mathrm{g} / 1 \mathrm{STa}$ (equivalent to 50000 mouse units) had been added. Net STa induced water and electrolyte movement was determined.

\section{MATERIALS}

Cholera toxin was obtained from the Swiss Serum and Vaccine Institute, Berne, and LT and STa from Sigma Chemical Company. Radiolabelled polyethylene glycol $\left({ }^{14} \mathrm{C}-\mathrm{PEG}\right.$ 4000) was obtained from Amersham International. Igmesine was kindly supplied by Institut de Recherche Jouveinal, Fresnes, France and all other chemicals were supplied by British Drug House.

\section{ANALYTICAL METHODS}

${ }^{14} \mathrm{C}-\mathrm{PEG}$ concentrations in the effluent were measured in triplicate by liquid scintillation spectroscopy in an LKB Wallac Ultra-beta 1210 scintillation counter. Mean net fluid movement was calculated from three consecutive effluent samples and expressed as $\mu \mathrm{l} / \mathrm{min} / \mathrm{g}$ dry intestinal weight. Positive values denote net absorption and negative values net secretion. Chloride concentration was determined by a Corning 925 chloride analyser, and sodium and potassium by flame photometry (Instrumentation Laboratories 943). Net solute movement is expressed as $\mu \mathrm{mol} / \mathrm{min} / \mathrm{g}$.

Steady state condition was confirmed by less than $5 \%$ variation in net water movement between consecutive 10 minute collections. Values were accepted only if ${ }^{14} \mathrm{C}-\mathrm{PEG}$ recovery fell between 95 and $105 \% .^{22}{ }^{23}$ 
Table 1 Effect of intravenous pretreatment with igmesine on cholera toxin induced jejunal net secretion of electrolytes

\begin{tabular}{llllr}
\hline Igmesine $(\mathrm{mg} / \mathrm{kg})$ & Net $\mathrm{Cl}^{-}$flux $(\mu \mathrm{mol} / \mathrm{min} / \mathrm{g})$ & Net $N a^{+}$flux $(\mu \mathrm{mol} / \mathrm{min} / \mathrm{g})$ & Net $K^{+}$flux $(\mu \mathrm{mol} / \mathrm{min} / \mathrm{g})$ & Number \\
\hline 0.00 & $-24(-29$ to -17$)$ & $-27(-33$ to -18$)$ & $-2.0(-2.0$ to -1.4$)$ & 29 \\
0.03 & $-19(-21$ to -17$)$ & $-24(-31$ to -17$)$ & $-1.7(-1.7$ to -1.5$)$ & 5 \\
0.10 & $-17^{\star}(-23$ to -11$)$ & $-17^{\star}(-27$ to -13$)$ & $-1.5^{\star}(-2.0$ to -1.2$)$ & 19 \\
0.30 & $-18^{\star}(-20$ to -15$)$ & $-14^{\star}(-16$ to -13$)$ & $-1.5(-1.7$ to -1.4$)$ & 9 \\
1.00 & $-18^{\star}(-20$ to 12$)$ & $-12^{\star}(-19$ to -10$)$ & $-1.4^{\star}(-1.6$ to -1.1$)$ & 10 \\
3.00 & $-16^{\star}(-16$ to -14$)$ & $-13^{\star}(-17$ to -8$)$ & $-0.9^{\star}(-1.0$ to -0.6$)$ & 8 \\
10.00 & $-11^{\star}(-13$ to -9$)$ & $-16^{\star}(-17$ to -16$)$ & $-1.3^{\star}(-1.5$ to -1.0$)$ & 8 \\
\hline
\end{tabular}

Data expressed as median (interquartile range).

${ }^{\star} \mathrm{p}<0.05$ compared with cholera toxin (Kruskal-Wallis test).

\section{STATISTICAL ANALYSIS}

Results are expressed as median and interquartile range in each group of animals studied. Differences in net fluid and electrolyte movement were examined using the Mann-Whitney test or a non-parametric analysis of variance (Kruskal-Wallis test with intergroup analysis) whenever appropriate. Cuzick's test for trend was applied to appropriate data sets.

When assessing the efficacy of igmesine or placebo in established secretion, data are expressed as percentage change in net fluid movement between the first and second periods of collection. This corrects for any baseline differences between groups. Positive percentages reflect reversal of secretion.

\section{Results}

BASAL STATE EXPERIMENTS

Basal net jejunal water movement (192.5 $\mu \mathrm{l} / \mathrm{min} / \mathrm{g}$ (149.5-237.8), $\mathrm{n}=14$ ) was unaffected by igmesine $(172.9 \mu \mathrm{l} / \mathrm{min} / \mathrm{g}$ (132.2-239.9), $\mathrm{n}=6)$. Net jejunal electrolyte movement paralleled net jejunal water movement (control: $\mathrm{Cl}^{-}$, $1.1 \mu \mathrm{mol} / \mathrm{min} / \mathrm{g}$ (-2.2 to 2.3$) ; \mathrm{Na}^{+}, 16.5(12.3$ to 18.5$) ; \mathrm{K}^{+}, 0.1$ (0.0 to 0.1 ); igmesine: $\mathrm{Cl}^{-}, 0.8$ ( -2.5 to 1.1 ); $\mathrm{Na}^{+}, 17.7$ (13.6 to 19.0$) ; \mathrm{K}^{+}, 0.1$ $(-0.1$ to 0.1$))$.

\section{CHOLERA TOXIN EXPERIMENTS}

Intravenous administration of igmesine before cholera toxin exposure

Cholera toxin produced net water secretion in all rats. Igmesine had an antisecretory effect at doses of $0.1,0.3,1,3$ and $10 \mathrm{mg} / \mathrm{kg}(\mathrm{p}=0.007$; fig 1). Although Cuzick's test for trend was positive $(p<0.0001)$, intergroup analysis re-

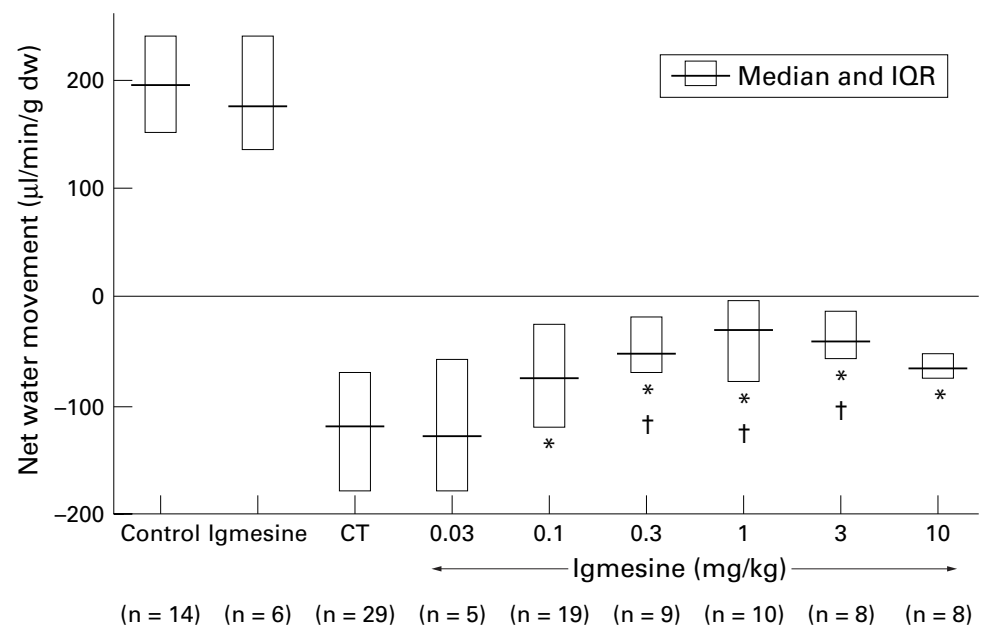

Figure 1 Effect of pretreatment with igmesine on cholera toxin (CT) induced jejunal net water secretion. Data expressed as median and interquartile range. ${ }^{\star} p<0.04$ compared with $C T ; t p<0.02$ compared with CT $+0.03 \mathrm{mg} / \mathrm{kg}$ igmesine (Kruskal-Wallis). vealed no significant difference in antisecretory effect above a dose of $0.1 \mathrm{mg}(\mathrm{p}>0.08)$. Net electrolyte movement was comparable with net water movement (table 1).

Intravenous administration of igmesine after exposure to cholera toxin

In keeping with a steady state, jejunal net water secretion did not change during the 30 minute collection periods pre- and post-saline (median reduction in secretion $17.6 \%$ (interquartile range $-2.8 \%$ to $38.1 \%$ ), $n=32$; $\mathrm{p}>0.05$, Mann-Whitney). An intravenous bolus of $0.3 \mathrm{mg} / \mathrm{kg}$ igmesine similarly failed to modify the steady state $(20.9 \%$ reduction $(-8.8 \%$ to $73.3 \%), \mathrm{n}=10)$. By contrast however, $1.0 \mathrm{mg} / \mathrm{kg}$ igmesine significantly reduced established cholera toxin induced jejunal net water secretion $(42.4 \%$ reduction in secretion $(23.7 \%$ to $67.4 \%), n=12 ; \mathrm{p}=0.04$; fig 2).

Luminal administration of igmesine after exposure to cholera toxin

A highly significant reduction in net water secretion $(57.4 \% \quad(41.6 \%$ to $66.7 \%), \mathrm{n}=8$; $\mathrm{p}=0.002$ ) occurred after the intrajejunal delivery of $6.0 \mathrm{mg} / \mathrm{kg}$ igmesine via the perfusate (fig 3).

LT AND STa EXPERIMENTS

Both LT and STa induced jejunal net water and electrolyte secretion in all rats. Pretreatment with $1 \mathrm{mg} / \mathrm{kg}$ igmesine significantly inhibited both LT and STa induced jejunal net secretion of water and electrolytes (fig 4, table 2).

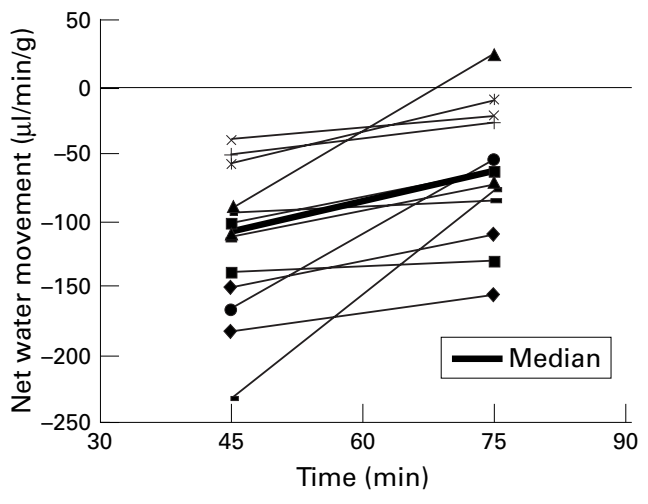

Figure 2 Effect of igmesine (1 $\mathrm{mg} / \mathrm{kg}$ intravenously) on established cholera toxin induced jejunal net water secretion. Net water secretion in individual rats $(n=12)$ is represented at 45 minutes (pre-igmesine) and at 75 minutes

(post-igmesine). $p<0.04$ compared with cholera toxin alone (Mann-Whitney test). 


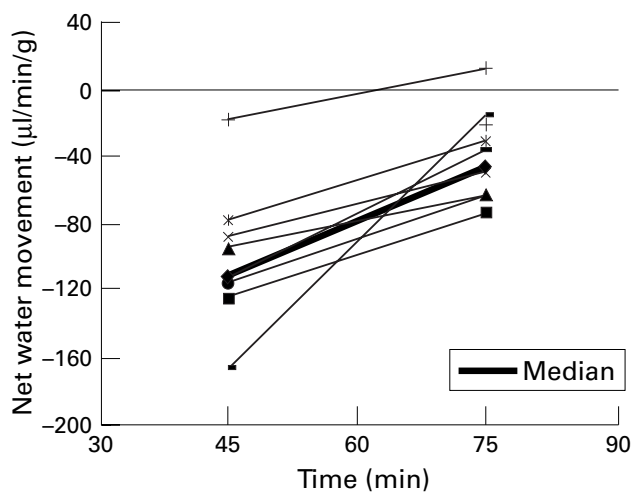

Figure 3 Effect of the addition of igmesine $(40 \mu \mathrm{g} / \mathrm{ml})$ to the perfusate, on established cholera toxin induced jejunal net water secretion. Net water secretion in individual rats $(n=8)$ is represented on equilibration at 45 minutes and after receiving $6 \mathrm{mg} / \mathrm{kg}$ igmesine, intrajejunally, at 75 minutes. $p<0.002$ compared with cholera toxin perfused with standard plasma electrolyte solution (Mann-Whitney test).

\section{Discussion}

The high affinity sigma ligand, igmesine, dose dependently inhibits cholera toxin induced jejunal net water and electrolyte secretion and reduces established cholera toxin induced secretion when given either as an intravenous bolus or intraluminally, in the perfusate. The maximal antisecretory dose was $1 \mathrm{mg} / \mathrm{kg}$, given intravenously. Igmesine also inhibits LT and STa induced secretion at that dose, but does not have any effect on basal water and electrolyte transport. These findings are in keeping with those of Carlisi et $a l^{24}$ who showed the antisecretory effect of sigma ligands, and of Rao and colleagues ${ }^{18}$ and Roze and colleagues ${ }^{19}$

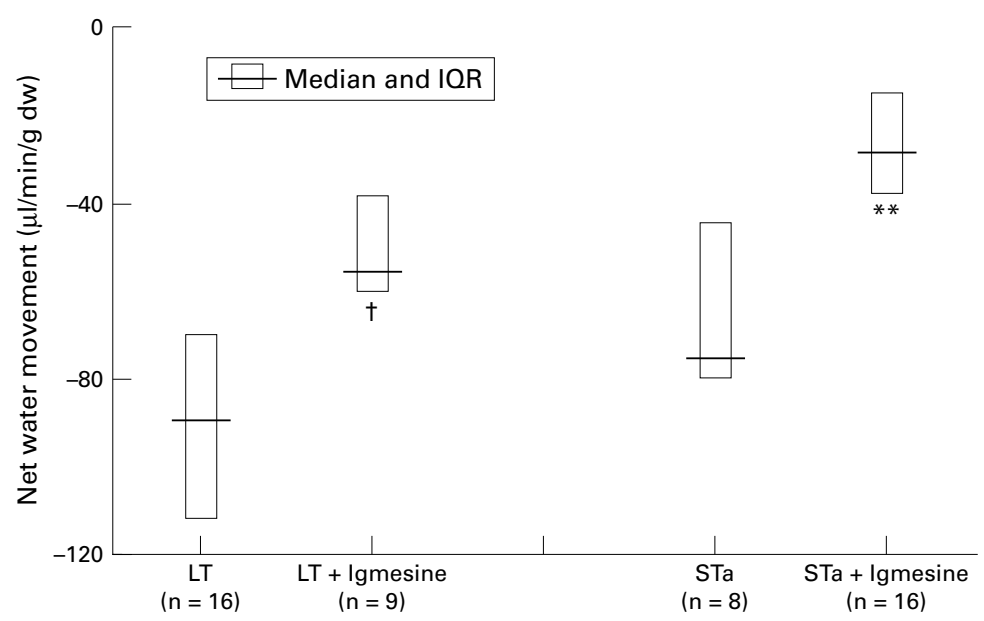

Figure 4 Effect of pretreatment with igmesine (1 $\mathrm{mg} / \mathrm{kg}$ intravenously) on heat labile (LT) and heat stable (STa) enterotoxin induced jejunal net water secretion. Data expressed as median and interquartile range. $t p<0.03$ compared with $L T ;{ }^{*} p<0.01$ compared with STa (Mann-Whitney test).

Table 2 Effect of igmesine (1 mg/kg intravenously) on Escherichia coli heat labile (LT) and heat stable (STa) enterotoxin induced jejunal net secretion of electrolytes

\begin{tabular}{lllll}
\hline & $\begin{array}{l}\text { Net } \mathrm{Cl}^{-} \text {flux } \\
(\mu \mathrm{mol} / \mathrm{min} / \mathrm{g})\end{array}$ & $\begin{array}{l}\text { Net } \mathrm{Na} \mathrm{a}^{+} \text {flux } \\
(\mu \mathrm{mol} / \mathrm{min} / \mathrm{g})\end{array}$ & $\begin{array}{l}\text { Net } \mathrm{K}^{+} \text {flux } \\
(\mu \mathrm{mol} / \mathrm{min} / \mathrm{g})\end{array}$ & Number \\
\hline LT & $-19(-28$ to -17$)$ & $-20(-24$ to -18$)$ & $-1.1(-1.4$ to -0.8$)$ & 16 \\
LT + igmesine & $-15^{\star}(-18$ to -13$)$ & $-10^{\star}(-13$ to -5$)$ & $-0.6^{\star}(-0.8$ to -0.5$)$ & 9 \\
STa & $-11(-14$ to -10$)$ & $-18(-20$ to -15$)$ & $-1.3(-1.5$ to -1.1$)$ & 8 \\
STa + igmesine & $-5.3+(-6$ to -5$)$ & $-7.6+(-9$ to -6$)$ & $-0.6+(-0.6$ to -0.6$)$ & 5 \\
\hline
\end{tabular}

Data expressed as median (interquartile range)

${ }^{\star} \mathrm{p}<0.02$ compared with $\mathrm{LT}, \mathrm{t} \mathrm{p}<0.02$ compared with STa (Mann-Whitney test). who found that igmesine inhibits both VIP induced secretion in vitro and prostaglandin induced secretion in humans, respectively. Riviere et al have also found that igmesine is proabsorptive in unstimulated mouse jejunum, in vitro. ${ }^{16}$

In a study of rat and mouse brain sigma sites, igmesine was compared with 1,3-di-otolyguanidine and haloperidol, the two compounds previously found to have a high affinity for the sigma site. Igmesine was more potent than 1,3-di-o-tolyguanidine and similar in affinity to haloperidol at inhibiting (+)SKF 10,047 binding to sigma sites. Igmesine has no significant affinity for a range of opioid, muscarinic, adrenergic, dopaminergic, serotoninergic, histaminergic, and GABAergic binding sites. ${ }^{17}$ It displaces tritiated (+)-SKF 10,047 from sigma sites in rat and mouse brain with $\mathrm{ID}_{50}$ values in the mouse of $1.2 \mathrm{mg} / \mathrm{kg}$ after intraperitoneal administration and $3.5 \mathrm{mg} / \mathrm{kg}$ when given orally. The displacement by igmesine is long lasting, with at least $60 \%$ inhibition of (+)-SKF 10,047 binding at four hours. The $\mathrm{ID}_{50}$ values are comparable with the intravenous and intraluminal doses of igmesine required in our study to inhibit enterotoxin induced secretion.

Cholera toxin, LT, and STa are thought to induce small intestinal secretion by different mechanisms of action. Cholera toxin and LT share a remarkable structural homology. Both are composed of a pentameric binding subunit and an enzymic subunit. The former attaches to an enterocyte ganglioside $\left(\mathrm{GM}_{1}\right)$ receptor which permits the latter to activate irreversibly a stimulatory $G$ protein on the basolateral membrane of the enterocyte. ${ }^{125}$ This results in the activation of adenylate cyclase and an increase in intracellular concentrations of cyclic AMP. ${ }^{23}$ Cyclic AMP is thought to initiate an intracellular signalling cascade resulting in phosphorylation of apical anion channels and efflux of chloride ions. ${ }^{26}{ }^{27}$ Differences between the two toxins have been recognised however. ${ }^{28-30}$ As well as the $\mathrm{GM}_{1}$ receptor, LT binds to a glycoprotein receptor which also activates adenylate cyclase. ${ }^{31}$ In addition, we have recently identified differences between the two in the recruitment of the secretagogue and neurotransmitter, 5-hydroxytryptamine (5HT). Cholera toxin is known to induce the release of 5-HT from enterochromaffin cells, stimulating secretion via adjacent mucosal $5-\mathrm{HT}_{2}$ receptors and $5-\mathrm{HT}_{3}$ receptors located on sensory dendrites. ${ }^{32} 33$ By contrast, LT does not induce 5-HT release and is not inhibitable by $5-\mathrm{HT}_{2}$ or $5-\mathrm{HT}_{3}$ antagonists. ${ }^{34}{ }^{35} \mathrm{STa}$ is a smaller toxin, which binds to and activates two membrane bound cyclic GMP dependent kinases on the cell surface. It initiates a secretory signalling cascade which is much more rapid in onset than cholera toxin and LT and is characterised by a rise in intracellular concentrations of cyclic GMP. ${ }^{4}$

Despite these differences, the antisecretory efficacy of igmesine implies a common pathway for these enterotoxins, on which the sigma ligand acts. This pathway is likely to involve components of the enteric nervous system. The role 
of the enteric nervous system in mediating more than $50 \%$ of cholera toxin and STa induced secretion was established by Lundgren et al who showed the inhibition of secretion by tetrodotoxin, lidocaine, and hexamethonium. ${ }^{5}$ LT has been studied in considerably less depth but we have confirmed that LT induced secretion is also inhibitable by neuronal blockade. ${ }^{35}$ It has been proposed that enterotoxins activate a neuronal secretory reflex composed of at least three enteric neurones. The first, a sensory neurone, has dendrites extending from the mucosa and relays information to an interneurone in the submucosal and myenteric plexuses. The interneurone then projects to a secretomotor efferent. The interneurone permits additional enteric and extrinsic neuronal inputs to modulate the reflex arc. Acetylcholine and VIP have been implicated as the secretory neurotransmitters of the secretomotor efferent for both cholera toxin and STa induced secretion. ${ }^{5}$ As sigma ligands inhibit VIP induced secretion and attenuate the actions of acetylcholine, modulation of this limb of the neuronal arc may represent the common pathway by which igmesine acts. Evidence for this comes, firstly, from the fact that sigma receptors are located in the myenteric plexus, the mucosa, and the submucosa of guinea pig small intestine. ${ }^{11}{ }^{12}$ Secondly, the proabsorptive effects of sigma ligands are neurally mediated. Riviere et al have showed that sigma ligands, including igmesine, induce a sustained decrease in short circuit current in mouse jejunum, in vitro, without effecting tissue conductance. ${ }^{16}$ This is prevented by the neural toxin, tetrodotoxin and the ganglionic blocker, chlorisondamine, implying the involvement of a preganglionic neurone in the sigma ligand effect.

The identification of the inhibitory neurotransmitter, neuropeptide Y (NPY), in efferent neurones further supports the suggestion of a common secretomotor pathway for cholera toxin, LT, and STa. NPY exhibits similar antisecretory properties to sigma ligands. ${ }^{16} \mathrm{It}$ is a potent inhibitor of VIP induced secretion and, like igmesine, inhibits both cholera toxin and STa induced secretion. ${ }^{36}{ }^{37}$ An identical pharmacological profile for NPY and sigma ligand stimulated duodenal alkaline secretion in the rat has been described. As a result it has been proposed that the endogenous peptides, NPY and PYY act through neuronal sigma binding sites. ${ }^{14}$

While the endogenous ligand for the sigma receptor has yet to be identified, Roman et al have reported that NPY and the related peptide YY have a high affinity for rat brain sigma receptors and that the distribution of NPY corresponds well with the distribution of sigma receptors. ${ }^{38}$ Tam et al have been unable to confirm this observation however. ${ }^{39}$ Furthermore, when Rao et al assessed the efficacy of igmesine and NPY in reversing VIP induced mouse ileal ion transport it was found that the addition of VIP antagonists significantly reduced the effects of VIP and igmesine but not of NPY. ${ }^{18}$ It was concluded that although sigma receptors suppress the action of released VIP, igmesine and NPY acted on different receptors. Thus, it now seems untenable that NPY and peptide YY act directly by binding to sigma sites. However, the situation in vivo is such that sigma agonists and NPY/peptide YY display very similar effects. They seem to use some common neural pathway in such a way that sigma sites, possibly through an endogenous ligand, are permissive to the NPY/ peptide YY effect. A similar model already exists as $\alpha_{2}$ antagonists block the peptide YY mediated inhibition of the effect of VIP in rat jejunum. ${ }^{40}$

In conclusion, the high affinity sigma ligand, igmesine, is an effective antisecretory agent against both cholera toxin and the two enterotoxins responsible for the majority of cases of travellers' diarrhoea. Igmesine probably acts via a secretory pathway common to all three enterotoxins, which is likely to be neuronal, involving NPY related mechanisms. The demonstration by Roze et al that igmesine strongly inhibits prostaglandin $\mathrm{E}_{2}$ induced secretion in human volunteers confirms the tolerability and efficacy of this agent in a clinical setting. ${ }^{19}$ The broad antisecretory effect of igmesine and its ability to reduce established secretion by over $50 \%$ make it a drug with the promise of therapeutic potential.

The authors gratefully acknowledge the receipt of an educational grant from Institut de Recherche Jouveinal, Fresnes, France.

1 Spangler BD. Structure and function of cholera toxin and the related Escherichia coli heat labile enterotoxin. Microbiol Rev 1992;56:622-47.

2 Cassel D, Pfeuffer T. Mechanism of cholera toxin action: covalent modification of guanyl nucleotide-binding protein of the adenylate cyclase system. Proc Natl Acad Sci USA 1978;75:2669-73.

3 Cassel D, Selinger Z. Mechanism of adenylate cyclase activation by cholera toxin: inhibition of GTP hydrolysis at the regulatory site. Proc Natl Acad Sci USA 1977;74:3307-11.

4 Guarino A, Cohen M, Thompson M, et al. Receptor binding and guanylate cyclase activation by Escherichia coli heat stable toxin. Am f Physiol 1987;253:G775-80.

5 Lundgren O, Svanik J, Jivegard L. Enteric nervous system, I. Physiology and pathophysiology of the intestinal tract. Dig Physiology and pathophysi $1989 ; 34: 264-83$.

6 Walker-Smith JA. Gastroenteritis and its sequelae. In: Walker-Smith JA, Murch S, eds. Diseases of the small intestine in childhood. 4th edn. London: Isis Medical Media Ltd, 1999:119-94.

7 Bennish ML. Cholera: pathphysiology, clinical features and treatment. In: Wachsmuth IK, Blake PA, Olsvik O, eds. Vibrio cholerae and cholera: molecular to global perspectives. Washington DC: American Society for Microbiology, 1994:229-55.

8 Gotuzzo E, Seas C, Echevarria J, et al. Ciprofloxacin for the treatment of cholera: a randomized, double-blind, controlled clinical trial of a single daily dose in Peruvian adults. Clin Infect Dis 1995;20:1485-90.

9 Martin W, Eades C, Thompson J, et al. The effects of morhine- and nalorphine-like drugs in the nondependent and morphine-dependent chronic spinal dog. $\mathcal{F}$ Pharmacol Exp Ther 1976;197:517-32.

10 Walker JM, Bowen WD, Walker FO, et al. Sigma receptors: biology and function. Pharmacol Rev 1990;42:355-402.

11 Roman F, Pascaud X, Vauche D, et al. Evidence for a nonopioid sigma binding site in the guinea-pig myenteric plexus. Life Sci 1988;42:2217-22.

2 Roman F, Pascaud X, Chomette G, et al. Autoradiographic ocalization of sigma opioid receptors in the gastrointestnal tract of the guinea pig. Gastroenterology 1989;97:76-82.

13 Campbell BG, Scherz MW, Keana JFW, et al. Sigma receptors inhibit contractions of the guinea pig ileum longitudinal muscle/myenteric plexus preparation elicited by both electrical stimulation and exogenous serotonin. $\mathcal{F}$ Neurosci 1989;9:3380-91.

14 Pascaud X, Chovet M, Roze C, et al. Neuropeptide Y and sigma receptor agonists act through a common pathway to stimulate duodenal alkaline secretion in rats. Eur $\mathcal{f}$ sharmacol duodenal alkaline

15 Riviere PJ, Pascaud X, Junien JL, et al. Neuropeptide Y and JO 1784 , a selective sigma ligand, alter intestinal transport
through a common, haloperidol-sensitive site. Eur $\mathcal{F}$ through a common, halop
Pharmacol 1990;187:557-9. 
16 Riviere PJ, Rao RK, Pascaud X, et al. Effects of neuropeptide Y, peptide YY and sigma ligands on ion transport in mouse jejunum. I Pharmacol Exp Ther 1993;264:1268-74

17 Roman FJ, Pascaud X, Martin B, et al. JO 1784, a potent and selective ligand for rat and mouse brain sigma-sites. $\mathcal{F}$ Pharm Pharmacol 1990;42:439-40.

18 Rao RK, Riviere PJ, Pascaud X, et al. Suppression of VIP-induced increases in ileal ion transport by sigma ligands [abstract]. Gastroenterology 1995;108:A170.

19 Roze C, Bruley des Varannes S, Shi G, et al. Inhibition of prostaglandin-induced intestinal secretion by igmesine in prostaglandin-induced intestinal secretion by igmes

20 Cassuto J, Fahrenkrug J, Jodal M, et al. Release of vasoactive intestinal polypeptide from the cat small intestine exposed to cholera toxin. Gut 1981;22:958-63.

21 Beubler E, Kollar G, Saria A, et al. Involvement of 5-hydroxytryptamine, prostaglandin $\mathrm{E}_{2}$, and cyclic AMP in cholera toxin-induced fluid secretion in the small intestine of the rat in vivo. Gastroenterology 1989;96:368-76.

22 Rolston DDK, Borodo MM, Kelly MJ, et al. Efficacy of oral rehydration solutions in a rat model of secretory diarrhoea. 7 Paediatr Gastroenterol Nutr 1987;6:624-30.

23 Elliot E, Watson A, Walker-Smith J, et al. Search for the ideal rehydration solution: studies in a model of secretory diarrhoea. Gut 1991;32:1314-20.

24 Carlisi VJ, Bilsky EJ, Horan PJ, et al. Blockade of naloxoneinduced morphine abstinence, but not morphine antinoiciception, by neuropeptide Y in the mouse [abstract].
Committee on Problems of Drug Dependence. Colorado: KeyCommittee on Prob
stone, 1992:2.

25 Field M. Modes of action of enterotoxin from Vibrio cholerae and Escherichia coli. Rev Infect Dis 1979;1:918 25.

26 Field M, Rao MC, Chang EB. Intestinal electrolyte transport and diarrheal disease I. N Engl f Med 1989;321: 800-6.

27 Chang EB, Rao MC. Intracellular mediators of intestinal electrolyte transport. In: Field M, ed. Diarrheal diseases. New York: Elsevier, 1991:49-72.

28 Griffith SL, Critchley DR. Characterisation of the binding sites for Escherichia coli heat-labile toxin type 1 in intestinal brush borders. Biochim Biophys Acta 1991;1075:15461.
29 Zemelman BV, Chu SW, Walker WA. Host response to Escherichia coli heat-labile enterotoxin via two microvillus Escherichia coli heat-labile enterotoxin via two microvillus membrane receptors

30 Donowitz M, Binder HJ. Effect of enterotoxins of Vibrio cholerae, Escherichia coli and Shigella dysenteriae type 1 on fluid and electrolyte transport in the colon. F Infect Dis 976;134:135-43.

31 Holmgren J, Fredman P, Lindblad M, et al. Rabbit intestinal glycoprotein receptor for Escherichia coli heat-labile enterotoxin lacking affinity for cholera toxin. Infect Immun 1982;38:424-33.

32 Nilsson $\mathrm{O}$, Cassuto $\mathrm{J}$, Larsson PA, et al. 5-Hydroxytryptamine and cholera secretion: a histochemical and physiological study in cats. Gut 1983;24:542-8.

33 Beubler E, Horina G. 5- $\mathrm{HT}_{2}$ and 5-HT 3 receptor subtypes mediate cholera toxin-induced intestinal fluid secretion in (1990;99:83-9.

34 Mourad FH, O'Donnell LJ, Dias JA, et al. Role of 5-hydroxytryptamine type 3 receptors in rat intestinal fluid and electrolyte secretion induced by cholera and Escherichia coli enterotoxins. Gut 1995;37:340-5.

35 Turvill JL, Mourad FH, Farthing MJG. Crucial role for 5-HT in cholera toxin but not Escherichia coli heat-labile enterotoxin-intestinal secretion in rats. Gastroenterology 1998;115:883-90.

36 Sjoqvist A, Fahrenkrug J, Jodal M, et al. The effect of splanchnic nerve stimulation and neuropeptide $\mathrm{Y}$ on cholera secretion and release of vasoactive intestinal polypeptide in the feline small intestine. Acta Scand Physiol 1988;133:289-95.

37 Tantisira MH, Jodal M, Lundgren O. Further studies of the changes in alkaline secretion, transepithelial potential difference and net fluid transport induced by the heat-stable enterotoxin of Escherichia coli (STa) in the rat jejunum in vivo. Acta Physiol Scand 1990;140:557-65.

38 Roman FJ, Pascaud X, Duffy O, et al. Neuropeptide Y and peptide YY interact with brain sigma and PCP binding peptide YY interact with brain sigma

39 Tam SW, Mitchell KN. Neuropeptide Y and peptide III do not bind to brain sigma and phenylcyclidine binding sites. Eur f Pharmacol 1991;193:121-2.

40 Souli A, Chariot J, Presset O, et al. Neural modulation of the antisecretory effect of peptide YY in the rat jejunum. Eur $\mathcal{F}$ Pharmacol 1997;333:87-92. 